\title{
The Effect of Profitability, Liquidity, Leverage and Company Size on Sukuk Yield With The Rating of Sukuk as Intervening Variables
}

\author{
Karimatus Syakdiyah ${ }^{1}$, Purnama Putra ${ }^{2 *}$ \\ ${ }^{1}$ Accounting Department, Universitas Islam 45, Indonesia \\ ${ }^{2}$ Islamic Banking Departement, Universitas Islam 45, Indonesia \\ *Corresponding author e-mail: purnama.p41@gmail.com
}

\begin{tabular}{ll}
\hline Article Info & Abstract \\
The purpose of this study was to test whether profitability, \\
Keywords: & liquidity, leverage, and company size affect the yield of Sukuk with \\
Profitability; & the Sukuk rating as an intervening variable. The method chosen to \\
Liquidity; & conduct this research is a quantitative method in which the data is \\
Leverage; & processed using path analysis The data used in this research is \\
Company size; & secondary data. The sample used is 12 companies for the period \\
Sukuk yield & 2012-2017. Findings. The results of this study can be concluded \\
& that partially profitability has a significant positive effect, liquidity \\
DOI: & has a significant negative effect, leverage has no effect and is not \\
$10.33830 /$ elqish.v1i1.1532.2021 & significant, company size has a significant positive effect on the \\
& Sukuk rating. While profitability has a significant negative effect, \\
& liquidity has no and insignificant effect, leverage has a significant \\
& negative effect, company size has no and insignificant effect, \\
& Sukuk rating has no and insignificant effect on Sukuk yield. The \\
& Sukuk rating cannot mediate the profitability and leverage \\
& variables on the Sukuk yield. However, the Sukuk rating can \\
mediate the liquidity variable and company size on the sukuk yield.
\end{tabular}

\section{Introduction}

The development of corporate Sukuk and state Sukuk in Indonesia has increased from year to year. During 2016, there were 14 corporate Sukuk series issuances with a total issuance value of IDR 3.82 trillion. Meanwhile, in the same period, there were 6 series of corporate Sukuk maturing with a total value of IDR 1,002 billion, so that by the end of December 2016, the number of outstanding corporate Sukuk reached 53 Sukuk with the proportion of total Sukuk reaching $10.58 \%$ of the 501 total number of Sukuk. and outstanding corporate bonds (www.ojk.go.id). The phenomenon in Indonesia is that several issuers fail to pay, which causes investors to experience a crisis of confidence in the company. There are several cases, namely, the case in 2009, the default risk occurred in PT Adhi Karya (Persero) Tbk (ADHI) who had to accept the fact that there was a rating downgrade from idA to idA-. The rating is given by Pefindo, whose period is from April 11, 2016 to April 1, 2017. Another case can be seen at PT. Bakrieland Development Tbk (ELTY). Pefindo in 2010, re-assigned the BBB + rating for PT Bakrieland Development Tbk (ELTY) and its corporate bonds I / 2008 valued at IDR 500 billion. Then in 2011, PEFINDO again lowered the corporate rating and bonds I/ 2008 series B of PT Bakrieland Development Tbk (ELTY) from idB to idCCC. (www.Pefindo.co.id) in Afiani (2013)

Investors and investors who are going to buy Sukuk must pay attention to several things, such as the Sukuk rating and the yield of the Sukuk. Through the Sukuk rating, investors can measure the level of risk and return on investment in a company. The better the rating the company's Sukuk has, the lower the risk level of failure of the Sukuk. So that this will indirectly become a condition for investing in this long-term capital market instrument.(Hamida, 2017)

Indarsih (2013) states that an owner of capital (investor) who will invest his funds in bond securities should pay attention to the company's Sukuk yield because this yield can provide 
information about the amount of profit to be received on the invested funds. Companies in issuing Sukuk will certainly expect benefits from their funding as seen from the financial statements contained in the Sukuk yield.

Profitability has a negative effect on bond yields(Faizah et al., 2015). The results of research conducted by Afiani (2013) show that there is no effect of the profitability variable simultaneously on the Sukuk rating. Pramesti states that profitability affects the ranking of the Sukuk(Pramesti, 2018).

Research conducted by Indarsih (2013) shows that liquidity does not affect bond yields. Contrary to the research results of Nurfauziah \& Setyarini (2004) which state that liquidity affects the yield of Islamic bonds. In contrast to the research of Yan He et al., (2005) in Hamida (2017) which states that liquidity has a positive effect on Sukuk yield. Nurmayanti \& Setiawati (2012) show that the current ratio has a significant positive relationship with bond ratings. In contrast to the research of Hadianto \& Wijaya (2010) and Fenny et al., (2017)which states that the liquidity ratio does not affect the Sukuk rating.

The research results of Nurakhiroh, et al.,(2014) state that leverage has a significant negative effect on the Sukuk rating. While the results of the research by Rusfika \& Wahidahwati (2017) show different results that leverage has a significant positive effect on bond ratings. Research conducted by Hamida (2017) shows a positive and significant effect of DER on Sukuk yield. According to Restuti (2007), Leverage has a significant negative effect on Sukuk yield(Faizah et al., 2015) However, the results of this study differ from Setyapurnama (2005) that DER does not have a significant effect on yield. It is proven in research conducted by Hendaryadi et al.(2018) and Surya \& Nasher (2011) that leverage has a positive and significant effect on Sukuk yield.

Research conducted by Aisah \& Haryanto (2014) shows that company size has a negative and significant effect on bond yields. Ibrahim (20 proved that size (company size) has a negative and significant effect on bond yields. Contrary to Pramesti (2017), which states that company size affects the ranking of the Sukuk. It is different with (Pinanditha \& Suryantini, 2016) which proves that the results of the company size analysis partially have a significant positive effect on the rating of the bonds. Research conducted by Nurfauziah \& Setyarini (2004) states that bond ratings do not have a significant effect on bond yields. Hendaryadi's research(2018) shows that bond ratings have a negative and significant effect on bond yields. Surya \& Nasher's research (2011) shows the same results that there is a negative and significant effect between bond ratings on bond yields.

Based on the explanations and phenomena that have been described above as well as the variety of research results that show inconsistencies in the results of the research, it is the reason for the emergence of background for conducting further research on the factors that affect the yield of Sukuk and Sukuk rank. The research design has been directed to use quantitative methods by processing multiple linear regressions. The novelty of the previous researchers, namely the researcher added two independent variables, namely the variable profitability and company size, this research period was in 2012-2017, and the research object of all companies that issued Sukuk and were listed on the Sharia Securities List, the author used the Sukuk ranking as an intervening variable because there are still very few people who conduct research related to the ranking of Sukuk as an intervening variable, so the authors are interested in conducting this research.

\section{Research Method}

The data used in this research is secondary data from annual reports taken from sources www.idx.co.id, related sites, journals, and books that can support the focus of this research. Secondary data is used in research because the data taken is more accurate, comes from a reliable 
source, is easier, more effective \& efficient because it will save more time, cost, and effort. The sample used in this research is the purposive sampling method. Sugiyono (2013) suggests that purposive sampling is a technique of determining the sample with certain considerations. The purposive sampling technique is where the researcher selects the sample based on the research objectives and the suitability of the criteria that have been determined by the researcher. (Pernanu \& Putra, 2016; Putra, 2016) The population of this study was 79 companies that issued Islamic bonds in the 2012-2017 observation year. The number of samples was 12 companies that issued Sukuk that met the criteria for the research observation period of six years, namely the period 2012-2017.

A variable is something that can differentiate or bring variation to a value. Values can be different at various times for the same object or person, or at the same time for different objects or people, Sekaran (2011). This study discusses the independent variables, namely the variable profitability (X1), liquidity (X2), leverage (X3), company size (X4), Sukuk rating (Y1) as an intervening variable, and Sukuk yield as the dependent variable (Y2) with the contribution of several previous researchers in the following table:

Table 1. Variables Definition

\begin{tabular}{ll}
\hline Variables & Contributors \\
\hline Y1 : Sukuk Rating & Afiani (2013), Fenny, et al.,(2017) Pramesti (2017) \\
Y2 : Sukuk Yield & Faizah, et al.,(2014), Hamida (2017), Indarsih (2013) \\
X1 : Profitability & Hadianto \& Wijaya (2010), Hasan \& Dana (2018), \\
& Afiani (2013) \\
X2 : Liquidity & Hamida (2017), Kurniawan \&Suwarti (2017), Winanti, \\
& et al (2017) \\
X3 : Leverage & Estiyanti \& Yasa (2011), Surya (2014), Tamara (2013) \\
X4 : Company Size & Pranoto, et al, (2017), Pinanditha \& Suryantini (2016) \\
\hline
\end{tabular}

The data obtained is then processed in version 23.0 of the Statistical Package for Social Science (SPSS) using multiple linear analysis to test the following hypotheses:

a. The effect of profitability on the Sukuk rating

b. The effect of liquidity on the Sukuk rating

c. Effect of leverage on the Sukuk rating

d. The effect of company size on the Sukuk rating

e. Effect of profitability on Sukuk yield

f. Effect of liquidity on Sukuk yield

g. Effect of leverage on Sukuk yield

h. Effect of company size on Sukuk yields

i. The effect of the Sukuk rating on the Sukuk yield

The study will explain the direct and indirect effects of the independent variables, namely profitability, liquidity, leverage, and company size, on the dependent variable, namely Sukuk yield, and the intervening variable, namely the Sukuk rating as seen in Figure 1.

\section{Results and Discussions}

According to Putra (2016) regression analysis is used to measure the strength of the relationship between two or more variables and show the direction of the relationship between the 
dependent variable and the independent variable, as well as to determine the value of the dependent variable explained by the independent variable used in the period. research.

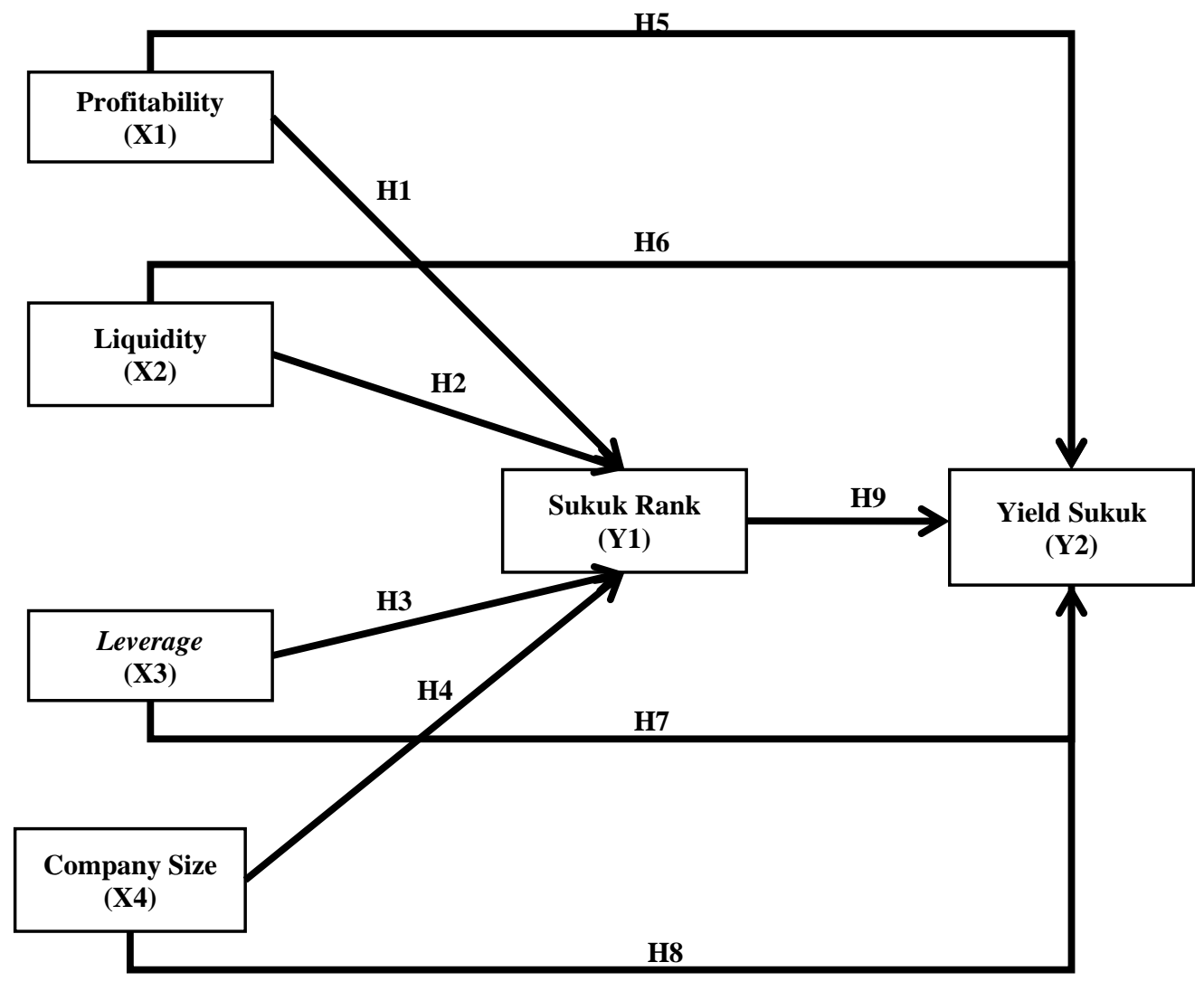

Figure 1. The relationship and effect between variables

\subsection{Sukuk Rank Regression Testing}

Table 2. Sukuk Rank Regression Testing

\begin{tabular}{llllll}
\hline & \multicolumn{2}{l}{$\begin{array}{l}\text { Unstandardized } \\
\text { Coefficients }\end{array}$} & \multicolumn{3}{l}{$\begin{array}{l}\text { Standardized } \\
\text { Coefficients }\end{array}$} \\
& \multicolumn{1}{l}{$\begin{array}{l}\text { Std. } \\
\text { Model }\end{array}$} & Error & Beta & $\mathrm{t}$ & Sig. \\
\hline 1(Constant) & -5.614 & 1.578 & & -3.557 & .001 \\
Profitability & 3.574 & 1.775 & .181 & 2.014 & .048 \\
Liquidity & -.172 & .057 & -.268 & -3.007 & .004 \\
Leverage & -.006 & .011 & -.046 & -.533 & .596 \\
Company Size & .410 & .052 & .708 & 7.953 & .000 \\
\hline
\end{tabular}

a. Dependent Variable: Sukuk Rank

Based on table 2, the multiple linear regression equation formula for the Sukuk ranking variable is as follows:

$$
\mathrm{Y}=-5,614+3,574 \text { PROF - 0.172 LIQ - 0.006 LEV + 0.410 SIZE }
$$

The results of the equation from the multiple linear regression analysis models above can be explained through the following statements:

a. The constant is -5.614 , meaning that this constant value indicates that if there is no $\mathrm{X}=0$ variable, the value of the Sukuk rating will decrease by -5.614 or if profitability, liquidity, 
leverage, and company size have a constant value (0), then the value of the Sukuk rating decreases. amounting to $-5,614$.

b. The profitability regression coefficient is 3.574 . This implies that for every one-unit increase in profitability, the Sukuk rating will increase by 3.574 with the assumption that the other independent variables of the regression model are fixed. So, the higher the profitability, the better the Sukuk rank will be obtained.

c. The liquidity regression coefficient is -0.172 and is negative, this indicates that liquidity has an opposite relationship with the Sukuk rating. This implies that with the increase in liquidity by one unit, the Sukuk rating variable will decrease by 0.172 with the assumption that each increase in the other independent variables of the regression model is constant. So, the higher the liquidity, the lower the Sukuk rating that will be obtained.

d. The leverage regression coefficient is -0.006 and has a negative sign, this indicates that leverage has an opposite relationship with the Sukuk rating. This means that for every one-unit increase in leverage, the Sukuk rating will decrease by 0.006 with the assumption that the other independent variables of the regression model are fixed. The higher the leverage, the lower the Sukuk rating that will be obtained.

e. The regression coefficient for company size is 0.410 . This implies that for every one-unit increase in the size of the company, the Sukuk rating will increase by 0.410 with the assumption that the other independent variables of the regression model are fixed. So, the larger the company size, the better the Sukuk rating will be.

\subsection{Sukuk Yield Regression Testing}

Table 3. Sukuk Yield Regression Testing

\begin{tabular}{|c|c|c|c|c|c|c|}
\hline \multirow[b]{2}{*}{ Model } & & \multicolumn{2}{|c|}{$\begin{array}{l}\text { Unstandardized } \\
\text { Coefficients }\end{array}$} & \multicolumn{3}{|c|}{$\begin{array}{l}\text { Standardized } \\
\text { Coefficients }\end{array}$} \\
\hline & & $\mathrm{B}$ & Std. Error & Beta & $\mathrm{t}$ & Sig. \\
\hline \multirow[t]{6}{*}{1} & (Constant) & 23.012 & 7.388 & & 3.115 & .003 \\
\hline & Profitability & -22.277 & 7.846 & -.228 & -2.839 & .006 \\
\hline & Liquidity & -.135 & .262 & -.042 & -.514 & .609 \\
\hline & Leverage & -.457 & .048 & -.724 & -9.577 & .000 \\
\hline & Company Size & -.179 & .309 & -.062 & -.578 & .565 \\
\hline & Sukuk Rank & -.863 & .525 & -.174 & -1.646 & .105 \\
\hline
\end{tabular}

a. Dependen variabel : yield sukuk

Based on table 3, the multiple linear regression equation formula for the yield variable of sukuk is as follows:

$$
\mathrm{Y}=23,012-22,277 \text { PROF -0,135LIQ -0,457LEV- 0,179SIZE - 0,863SR }
$$

The results of the equation from the multiple linear regression analysis models above can be explained through the following statements:

a. A constant of 23.012 means that this constant value indicates that if the value of the independent variable (free) profitability, liquidity, leverage, and company size is 0 (zero) or there are no independent variables, the Sukuk yield will reach a value of 23.012. 
b. The profitability regression coefficient is $-22,277$ and is negative, this indicates that profitability has an opposite relationship with the yield of Sukuk. This implies that with the increase in profitability by one unit, the yield variable for the Sukuk will decrease by -22,277 with the assumption that any increase in the other independent variables from the fixed model. This shows that if the profitability is high, the resulting yield will be lower.

c. The liquidity regression coefficient is -0.135 . This implies that with the increase in liquidity by one unit, the yield variable for Sukuk will decrease by -0.135 with the assumption that any increase in the other independent variables from the fixed model. This shows that if liquidity is high, the resulting yield will be lower.

d. The leverage regression coefficient is -0.457 and is negative, this indicates that leverage has an opposite relationship with the yield of Sukuk. This implies that with the increase in leverage by one unit, the yield variable for Sukuk will decrease by -0.457 with the assumption that any increase in the other independent variables from the fixed model. This shows that if the leverage increases, the resulting yield will be low

e. The regression coefficient for company size is -0.179 and is negative, this indicates that company size has an opposite relationship with the yield of Sukuk. This implies that an increase in the size of the company by one unit will decrease the yield of the Sukuk variable by -0.179 with the assumption that any increase in the other independent variables from the fixed model. This shows that if the size of the company is large, the yield that will be received will be lower.

f. The regression coefficient for the Sukuk rank is -0.863 and is negative, this indicates that the Sukuk rank has an opposite relationship with the yield of the Sukuk. This implies that a oneunit increase in the Sukuk rating will decrease the yield of the Sukuk variable by -0.863 assuming that any increase in the other independent variables from the fixed model. This indicates that if the Sukuk rating is good or high, the yield that will be received will be lower.

\subsection{Analysis and Discussion}

\section{Profitability on the Sukuk Rating}

Based on table 2, it is obtained that the t value of profitability is 2.014 and t table is 1.996 with a significance value of 0.048 , which means that the profitability proxied by Return On Asset (ROA) has a positive and significant effect because the $t$ value is greater than the table and the significance value is smaller than 0.05 . The first hypothesis in this study is accepted. The results of this study are by the results of research in Pebruary (2016) which found that profitability has a significant positive effect on the Sukuk rating, because if the higher the profitability, the higher the net profit is obtained, which will increase the Sukuk rating for companies that issue Sukuk.

\section{Liquidity to the Sukuk Rating}

Based on table 2, the liquidity variable has an at-count value of -3.007 and at the table of 1.996, and a significance value of 0.004 is obtained, which means that liquidity, which is proxied by the Current Ratio (CR), has a negative and significant effect because the t value is greater than the $t$ table and the value the significance is less than 0.05 . This is supported by research by Manurung et al.(2009) which states that liquidity has a significant negative effect on bond ratings. The results of this study are supported by Pramesti (2018) which proves that liquidity has a significant negative effect on the Sukuk rating. This indicates that liquidity can affect the Sukuk rating. 


\section{Leverage on the Sukuk Rating}

Based on the t-test in table 2 which has been done previously, it shows that the $t$ value is 0.533 and the $t$ table is 1.996 with a significance of $(0.596)$ which means that leverage is proxied by the Debt to Equity Ratio (DER) and has a negative and insignificant effect because $t$ value is smaller than $t$ table and the significance value is greater than 0.05 . The third hypothesis in this study is rejected by stating that leverage has no and insignificant effect on the Sukuk rating. The results of this study are in line with research by Afiani (2013) which shows that leverage does not affect Sukuk ratings. Thus, changes in the increase or decrease in leverage do not affect the Sukuk rating.

\section{Company Size on Sukuk Rating}

Table 2 shows that the size of the company has a value of 7.953 and at a table of 1.996, while a significant value of (0.000) means that the size of the company as measured by Log Natural Total Asset (Ln) has an effect. positive and significant to the Sukuk rating because the t value is greater than the t table and the significance value is less than 0.05 . With a coefficient value of $(7,953)$, it can be concluded that company size has a positive and significant effect on Sukuk ratings, and following the results of research by Afiani (2013) which proves that company size has a positive and significant effect on Sukuk ratings. This means that according to the hypothesis the greater the size of the company, the higher the Sukuk rating the company gets.

\section{Effect of Profitability on Yield Sukuk}

Based on the t-test in table 3 which has been done previously, it shows that the t value of profitability is -2.839 and t table is 1.996 with a significant value of (0.006) which means that profitability is proxied using Return on Assets (ROA) has a negative and significant effect on yield. sukuk because the $t$ value is greater than t-table and the significance value is smaller than 0.05 . With a coefficient value of $(-2,839)$, it can be concluded that profitability has a negative and significant effect on Sukuk yield. This is supported by the results of research by Fristi, Elizabeth, \& Juwita (2017) which state that profitability has a negative and significant effect on Sukuk yield. This shows that the higher the level of profitability, the lower the risk of failure will result in a lower yield.

\section{Effect of Liquidity on Sukuk Yield}

Table 3 shows that liquidity has a $t$ value of -0.514 and a t table of 1.996 with a significant value of (0.609) which means that liquidity is proxied using Current Ratio (CR) has no effect and is not significant. to the yield of Sukuk because the $t$ value is smaller than the table and the significance value is greater than 0.05 . The results of this study are in line with the results of Indarsih's (2013) study which states that liquidity does not affect Sukuk yield

\section{Effect of Leverage on Sukuk Yield}

Based on the results of the t-test in table 3 which has been done previously, it shows that leverage has a t count of -9.577 and a t table of 1.996 with a significant value of (0.000) which means that leverage is proxied using the Debt to Equity Ratio (DER) and has a negative effect and significant to the yield of Sukuk because the $t$ value is greater than the $t$ table and the significance value is smaller than 0.05 . With a coefficient value of $(-0.578)$, it can be concluded that leverage has a negative and significant effect on Sukuk yield. This shows that the higher the leverage, the Sukuk yield will decrease or get smaller. 


\section{Effect of Company Size on Sukuk Yield}

Based on the results of the t-test in table 9 which has been done previously, it shows that the size of the company has a t count of -0.578 and a t table of 1.996 with a significant value of $(0.565)$ which means that the company size proxied using Log Natural Total Asset (Ln) is not has an effect and is not significant to the yield of Sukuk because the $t$ value is smaller than the table and the significance value is greater than 0.05 . Thus, the negative coefficient sign indicates that the larger the size of the company, the lower the yield will be. The results of the study are following the results of research by Faizah et al. (2015) which proved that company size has no and insignificant effect on the yield of Sukuk.

\section{Effect of Sukuk Rating on Sukuk Yield}

Based on the results of the $t$ test in table 9 which has been done previously, it shows that the rank of the sukuk has a t count of -1.646 and a t table of 1.996, a significant value of (0.105) with a coefficient value of (-1.646), so it can be concluded that the rank of Sukuk is not has a negative and insignificant effect on the yield of Sukuk because the $t$ value is smaller than the table and the significance value is greater than 0.05 . Following the direction of the negative coefficient, companies that have high bond ratings will usually give low yields because they have low risk as well. The results of this study are consistent with the results of research by Nurfauziah \& Setyarini (2004) which proved that the rank of Sukuk has no significant effect on the yield of Sukuk. This indicates that there is a weak relationship between the Sukuk rating and the yield of the Sukuk.

\section{The effect of profitability, liquidity, leverage, and company size on the yield of sukuk with sukuk rating as an intervening variable.}

Based on the results of hypothesis testing, it can be concluded that profitability does not directly affect the yield of Sukuk through the Sukuk rating because the value of the direct effect is $(-0.228)$ and the indirect effect is $(-0.032)$, which means that the value of the direct effect is greater than the indirect effect. This means that the Sukuk rating is not able to mediate the effect of profitability on the yield of the Sukuk.

Based on the results of hypothesis testing, it proves that the liquidity ratio indirectly affects the yield of the sukuk through the sukuk rating because the value of the direct effect is $(0.042)$ and the indirect effect is (0.047), which means that the value of the direct effect is smaller than the indirect effect. This means that the sukuk rating can mediate the effect of liquidity on the yield of the Sukuk. The results of this study are by the results of research by Hamida (2017) which shows that the higher the current ratio of the company, the higher the current assets of the company that are used for operations and to pay off short-term liabilities.

Based on the results of the hypothesis test, it proves that the leverage ratio indirectly affects the yield of the sukuk through the sukuk rating because the value of the direct effect is $(-0.724)$ and the indirect effect is (0.008), which means that the value of the direct effect is smaller than the indirect effect. This means that the sukuk rating is able to mediate the effect of leverage on the yield of the sukuk. The results of this study are consistent with research by Damayanti \& Fitriyah (2013) which proves that the leverage ratio affects the Sukuk rating. This means that the low leverage in a company indicates that the proportion of use of debt to finance investment against the capital owned has a good ability.

Based on the results of the hypothesis test, it proves that the size of the company indirectly affects the yield of the sukuk through the sukuk rating because the value of the direct effect is ($0.062)$ and the indirect effect is $(-0.123)$, which means that the value of the direct effect is smaller 
than the indirect effect. This means that the sukuk rating is able to mediate the size of the company to the yield of the sukuk. Thus the size of a company is very influential in determining the company's sukuk rating. So, the bigger the size of the company, the more it will be known by the public, so that more information about the company will be accepted by investors.

\section{Conclusions}

Based on the analysis and research results by testing the hypothesis using multiple regression analysis, it can be concluded that profitability has a positive and significant effect on the Sukuk rating, liquidity has a negative and significant effect on the Sukuk rating, leverage does not have a significant effect on the Sukuk ranking. company size has a positive and significant effect on Sukuk rating, profitability has a negative and significant effect on Sukuk yield, liquidity does not have a significant effect on Sukuk yield, leverage has a negative and significant effect on Sukuk yield, firm size has no significant effect on Sukuk yield, Sukuk rating has no significant effect on the yield of Sukuk, the profitability variable does not have a direct effect on the yield of the Sukuk through the Sukuk rating, liquidity indirectly has an influence on the yield of Sukuk through the Sukuk rating, leverage indirectly has an effect on the yield of Sukuk through the Sukuk rating, company size indirectly has an effect on the yield of Sukuk through the Sukuk rating. It is hoped that the next researcher will be able to expand the sample criteria by using companies that were still active at the time the research was carried out. With the aim that the data used is kept fresh and up to date, further research is expected to be able to examine other variables or replace the proxies for variables that are not significant in this study, so that it will provide results that describe what things can affect. Sukuk ranking and yield of Sukuk, further research is expected to extend the research period so that the results obtained can be more accurate and generalized so that they can produce better results.

\section{References}

Afiani, D. (2013). Pengaruh Likuiditas, Produktivitas, Profitabilitas, Dan Leverage Terhadap Peringkat Sukuk. Accounting Analysis Journal, 2(1).

Aisah, S. H., \& Haryanto, A. M. (2014). Analisis Faktor-Faktor yang Mempengaruhi Yield Obligasi Korporasi (Studi kasus pada seluruh perusahaan penerbit obligasi yang terdaftar di BEI periode 2010-2012). Fakultas Ekonomika dan Bisnis.

Damayanti, E. W., \& Fitriyah, F. (2013). Pengaruh Corporate Governance Dan Rasio Akuntansi Terhadap Peringkat Obligasi. IQTISHODUNA, 9(1).

Faizah, Y. L. N., Suyono, E., \& Ramadhanti, W. (2015). Pengaruh Profitabilitas, Likuiditas, Size dan Leverage Perusahaan terhadap Yield Obligasi dengan Peringkat Obligasi Sebagai Variabel Intervening. AKUNTABEL, 5(1).

Fenny, F., Effendi, R., \& Artina, N. (2017). Analisis Pengaruh Likuiditas, Profitabilitas dan Solvabilitas terhadap Peringkatan Obligasi Syariah pada Perusahaan yang menerbitkan Obligasi Syariah di Bursa Efek Indonesia Periode 2014-2016. Jurnal Manajemen, 1(1).

Ghazali, I. (2016). Aplikasi Analisis Multivariete dengan IBM SPSS 23 (Vol. VIII). Badan Penerbit Universitas Diponegoro.

Hadianto, B., \& Wijaya, M. S. V. (2010). Prediksi Kebijakan Utang, Profitabilitas, Likuiditas, Ukuran, Dan Status Perusahaan Terhadap Kemungkinann Penentuan Peringkat Obligasi: Studi Empirik Pada Perusahaan Yang Menerbitkan Obligasi Di Bursa Efek Indonesia. Jurnal Manajemen Teori Dan Terapan| Journal of Theory and Applied Management, 3(3). 
Hamida, L. (2017). Pengaruh Likuiditas dan Leverage Terhadap Yield Sukuk dengan Peringkat Sukuk sebagai Variabel Intervening (Study Pada Perusahaan Non Keuangan di Bursa Efek Indonesia). Jurnal Ekonomi Dan Bisnis, 18(1), 71-86.

Hendaryadi, Yusniar, M. W., \& Hadi, A. (2018). Pengaruh Tingkat Suku Bunga, Bond Rating, Ukuran Perusahaan, Debt To Equity Ratio (DER) Terhadap Yield To Maturity Obligasi Korporasi Di BEI Periode Tahun 2010-2012. Jurnal Wawasan Manajemen, 6(3), 209-309.

Indarsih, N. (2013). Pengaruh Tingkat Suku Bunga SBI, Rating, Likuiditas Dan Maturitas Terhadap Yield To Maturity Obligasi. Jurnal Ilmu Manajemen (JIM), 1(1).

Manurung, A., Silitonga, D., \& Tobing, W. R. L. (2009). Hubungan Rasio-rasio Keuangan dengan rating obligasi. PT Finansial Bisnis Informasi Jakarta.

Nurakhiroh, T., Fachrurrozie, F., \& Jayanto, P. Y. (2014). Pengaruh Rasio Keuangan Terhadap Rating Sukuk dengan Manajemen Laba Sebagai Variabel Intervening. Accounting Analysis Journal, 3(1).

Nurfauziah, N., \& Setyarini, A. F. (2004). Analisis Faktor-faktor yang Mempengaruhi Yield Obligasi Perusahaan (Studi Kasus pada Industri Perbankan dan Industri Finansial). Jurnal Siasat Bisnis, 2(9).

Nurmayanti, P., \& Setiawati, E. (2012). Bond rating dan pengaruhnya terhadap laporan keuangan. PEKBIS (Jurnal Pendidikan Ekonomi Dan Bisnis), 4(02).

Pebruary, S. (2016). Pengaruh Rasio Profitabilitas, Rasio Likuiditas, Rasio Leverage dan Pendapatan Bunga Terhadap Rating Sukuk Korporasi Periode 2010-2013. Jurnal Dinamika Ekonomi \& Bisnis, 13(1).

Pernanu, I. G., \& Putra, P. (2016). Pengaruh Motivasi dan Kepuasan Kerja terhadap Kualitas Pelayanan : Survey pada Karyawan BTN Kantor Cabang Syariah Kota Bekasi. Maslahah, 7(2), 15-32.

Pramesti, W. (2018). Analisis pemeringkatan sukuk: Perspektif keuangan. BISNIS: Jurnal Bisnis Dan Manajemen Islam, 5(1), 93-110.

Putra, P. (2016). Pengaruh Pembiayaan Mudharabah, Musyarakah, Murabahah, Dan Ijarah Terhadap Profitabilitas 4 Bank Umum Syariah Periode 2013-2016. Jurnal Organisasi Dan Manajemen, 14(10), 140-150.

Rusfika, R., \& Wahidahwati, W. (2017). Kemampuan Faktor Akuntansi dan Non Akuntansi dalam Memprediksi Bond Rating. EKUITAS (Jurnal Ekonomi Dan Keuangan), 1(1), 85-103.

Sugiyono. (2013). Metode Penelitian Kuantitatif Kualitatif dan $R \& D$. Alfabeta.

Surya, B. A., \& Nasher, T. G. (2011). Analisis pengaruh tingkat suku bunga sbi, exchange rate, ukuran perusahaan, debt to equity ratio dan bond terhadap yield obligasi korporasi di indonesia. Jurnal Manajemen Teknologi, 10(2), 186-195.

Yulia Fristi, A., Megawati Elizabeth, S., \& Juwita, R. (2017). Pengaruh Tingkat Suku Bunga, Return On Asset Dan Peringkat Obligasi Terhadap Yield Obligasi Pada Sektor Perbankan Yang Terdaftar Di Bursa Efek Indonesia Periode 2012-2015. Jurnal Manajemen, 1(1). 